\title{
A Child's Questions
}

\section{William E. Bohn}

To cite this article: William E. Bohn (1916) A Child's Questions, The Pedagogical Seminary, 23:1, 120-122, DOI: 10.1080/08919402.1916.10534697

To link to this article: http://dx.doi.org/10.1080/08919402.1916.10534697

曲 Published online: 30 Aug 2012.

Submit your article to this journal $\pi$

LII Article views: 4

Q View related articles $₫$

4 Citing articles: 1 View citing articles 


\title{
A CHILD'S QUESTIONS
}

\author{
By William E. Boнn, Ethical Culture School, New York City
}

A part of our difficulty about education results from the fact that trained educationists usually limit their observation to children more than five years old reacting under schoolroom conditions. Yet it is indubitable that the most important facts about life are learned before the fifth birthday and that the child's natural curiosity and inventiveness have freest play outside of school. The fragmentary materials of this paper are set down as an indication of the range of intellectual interests of a child up to the beginning of the sixth year.

The author hopes, however, that the form of the material will not be without a certain suggestiveness. He hazards the conjecture that in all of our child study we have too much neglected the very simplest guide. For physical education and for many aspects of intellectual development highly specialized tests are, no doubt, requisite. But for the discovery of the nature and range of a child's intellectual interests the child's own spontaneous questions are surely the most reliable indication. Despite the discouraging ignorance or carelessness of parents and nurses all normal children persistently inquire about their universe. If the questions often seem stupid and monotonous it is because previous ones have not been adequately answered. A child whose questions are answered will follow old queries with new ones progressively intelligent.

And these questions are something more than materials for observation. They furnish the occasions, the impulses, for the educational process. At the moment of putting a question a child will listen with interest to any answer. He will even, in the fourth or fifth year, follow out an extended demonstration or make observations covering several days.

$R^{\prime}$ 's question about how water flows up in the pipes is a case in point. She assisted for an hour while a member of the family constructed a miniature water system in the bathroom. Several days later she took a great interest in the city reservoir when she was taken to see it. Of course she could not understand the principles of physics involved in the distribution of the water, but she understood the method of distribution in its main features-far better, no doubt, than many of her adult townspeople. She was then in her fifty-sixth month. Eight months later she happened, of her own accord, to get to talking about this experience and showed, in response to questions, that she remembered the chief part of what she had learned. Several similar cases could be cited to show that the interest indicated by a child's question may be deep and comparatively permanent.

The record of R's questions is extremely fragmentary. The questions are in nearly all cases set down exactly as they were asked, but very few out of many thousands have been preserved. A more generous record would show that she has covered a very wide range of the affairs of man and nature. She has asked about her own anatomy, all sorts of mechanical devices, the lives of her parents, the growth of plants and animals, the origin and nature of the earth and heavenly bodies, the wind and weather, the origin and future life of man,- 
and so on ad infinitum. She is not at all an abnormal child. The author has observed several other children whose questions covered an equally wide range. No doubt the average child furnishes us before his sixth year with the opportunity to lay for him a considerable foundation for an intellectual life.

To be sure many of the questions can be answered only fragmentarily. Many of the answers, moreover, will be so misunderstood as to add shadows to the dark places. At best some of queries put at five cannot be answered at fifty-and could not be if the eager questioner were to live to be five hundred. They are among the permanent human problems. But these are precisely the questions which must be answered carefully and honestly if the child is to go on from question to question and from answer to answer. If he asks in all seriousness where he came from and how the earth was made and is put off with palpable fabrications he will come to think that the adults are not concerned with these matters so vital to him or are ignorant concerning them. So he will grow uncommunicative. And when, later, he goes to school and a lot of information he never asked for is hurled at him he may be set down as "unresponsive," "intractable," or "subnormal."

On the other hand, if his questions are answered he will develop a right attitude. He may misunderstand the replies or forget them; but he will come to regard the world as an intelligible place, and intelligible for him. And this attitude is what we are working for.

\section{List of Questions}

I8th month. Mamma, daddie-rain? (R's father was not at home and it had begun to rain. The question meant: Mamma, is daddie out in the rain? The importance of it lies in the indication (I) of imagination, and (2) of concern for the welfare of another person.)

Igth month. What that? (This question was asked while $R$ was looking at a picture. It became a formula applicable to anything which she did not understand. Later in the same month it changed to " $R$ don't know that," and in the 23rd month to " $R$ want to know that."

26th month. What Mother and Daddie talking about? Right-wrong. What is right? What is wrong?

27th month. Where do eggs come from? What do mammas lay? (This question resulted, naturally, from the answer given to the preceding one.)

28th month. Fall-fell. Fall-fell. What is fall? What is fell? 29th month. What is the navel for?

3Ist month. $R$. Daddie, were there any people here before we were? Father. Yes.

$R$. How did they get here?

Father. They were born just as we were.

$\mathrm{R}$. Was the earth here before there were any people?

Father. Yes.

R. How did it get here if there were no people to make it?

33 rd month. Daddie, did you ever notice that when you have been away for a long time your own house looks strange, like some other house?

38 th month. Why do they call a cow a cow?

42nd month. Mother, where is your mother? Where did she go? (In varying forms this question was often repeated.)

43rd month. Who made the earth? Was there ever a time when we 
weren't on earth? (These questions were asked while $R$ was modeling in clay.)

53rd month. Before the first mother was there a mother?

55 th month. There are two meanings for the word globe. One is a "sphere," the other is "the paper." Why do they call the paper The Globe?

56 th month. How does water run up in pipes?

57th month. How did the first man get here without any mother? How was the water made? What is rock made of ?

58th month. What is sleepy-sand? How does it get into our eyes in the morning? Why don't we say twenty-ten after twenty-nine? (The explanation of the decimal system which followed this question helped $R$ to learn to count.) Won't you tell me what the names of the days of the week mean? Mother, shall we love each other as long as we live?

6oth month. Can I dig down and make a volcano? Has water ever been here where our house is now?

6rst month. ( $R$ had been sitting silent in her room.) Daddie, is all this here?

Father. All what?

R. All these things. Is it true that I am seeing all these things? Father. You can see them and feel of them and they are always here.

R. No; they are not always here. When I turn around they are not here.

Father. But when you turn back they are always just where you left them.

$R$. They are all alive. They keep coming and going. The nearer I go to them, the nearer they come to me.

Father. But aren't they always in the same place?

$R$. No; I just dream them, and they come and go in my dream. (After making this answer $\mathrm{R}$ went softly about the room touching objects and saying, "See them come and go.") 